\title{
KONTRIBUSI DAYA LEDAK OTOT TUNGKAI DAN DAYA LEDAK OTOT LENGAN TERHADAP KEMAMPUAN TOLAK PELURU TEKNIK O'BREIN
}

\author{
Ali Mardius ${ }^{1}$, Yuni Astuti², Kibadra ${ }^{3}$ \\ ${ }^{1}$ Universitas Bung Hatta, Sumatera Barat, Indonesia ${ }^{1}$ \\ Universitas Negeri Padang, Sumatera Barat, Indonesia ${ }^{2,3}$ \\ e-mail : alimardius@bunghatta.ac.id ${ }^{1}$, yuniastuti@ fik.unp.ac.id ${ }^{2}$, kibadra@ fik.unp.ac.id ${ }^{3}$
}

\begin{abstract}
Abstrak
Penelitian ini bertujuan untuk menentukan kontribusi daya ledak otot tungkai dan daya ledak otot lengan terhadap kemampuan teknik O'Brein dalam tolak peluru. Penelitian ini merupakan metode yang bersifat kuantitatif dengan menggunakan desain penelitian korelasional. Populasinya adalah atlet UKO Universitas Bung Hatta sebanyak 40 atlet. Diambil secara purposive random sampling sebanyak 30 atlet. Instrumen standing broad jump digunakan untuk mengukur daya ledak otot tungkai. Medicine ball put tes digunakan untuk mengukur daya ledak otot lengan dan keterampilan teknik O'Brein digunakan untuk mengukur kemampuan tolak peluru.Hasil secara empiris menunjukkan bahwa: 1) kontribusi daya ledak otot tungkai dengan kemampuan tolak peluru teknik O'Brein yaitu 14,36\% 2) kontribusi daya ledak otot lengan dengan kemampuan tolak peluru teknik O'Brein 19,18\%. 3) kontribusi daya ledak otot tungkai dan lengan secara bersama-sama terhadap kemampuan tolak peluru teknik O'Brein adalah 25,70\%.
\end{abstract}

Kata Kunci : Daya letak otot tungkai, daya ledak otot lengan, kemampuan tolak peluru, teknik o'brein

\begin{abstract}
The study aims to determine the contribustion of explosive power arm and leg muscles personal or groups with the ability the O'brein technique ini shot put.The research was a guantitative method using corelational research design. The population was athlete track and field UKO University Bung Hatta as much as 40 athlete. Was taken by purposive random sampling as much as 30 athlete. The instrument standing broad jump was used to measure leg muscles explosive power. The instrument medicine ball put tes was used to measure arm muscles explosive power and skil of the technique o'brain was used to measure shot put.The result empirically showed that: 1) the contribution of leg muscle explosive power of the shot put capability was 14,36\% 2) the contribution of the explosive power of the arm muscles shot put athlete track and field ability was 19,18\%.3) the contribution of leg and arm muscle explosive power joinly to word o'brain technique short put was $25,70 \%$

Key words : The location of the leg muscles, the explosive power of the arm muscles, the ability to reject bullets, the technique Geez.
\end{abstract}

@Edukasi: Jurnal Ilmu Pendidikan FIP UPTT 2019

$\triangle$ Corresponding author :

Address :

Email

ISSN 2656-8063 (Media Cetak)

Phone ISSN 2656-8071 (Media Online) 
163 Kontribusi daya ledak otot tungkai dan daya ledak otot lengan terhadap kemampuan tolak peluru teknik O 'breinAli Mardius, Yuni Astuti, Kibadra

\section{PENDAHULUAN}

Kegiatan shot di lintasan dan lapangan memiliki sejarah yang menarik dengan perubahan signifikan total yang dilakukan sepanjang tahun. Pada tahun 1951, penembak tembakan Amerika, Parry O'Brien, menyempurnakan teknik gerakan menyamping menjadi teknik yang sekarang dikenal sebagai luncuran. Sejak awal 1980-an, teknik therotational (spin), gaya yang mirip dengan lempar cakram, di antaranya telah mendapatkan popularitas (Judge, \& Young. (2011).

Saat ini kedua teknik tersebut sedang digunakan oleh para pelempar top di dunia. Kinerja kompetitif tola peluru di trek dan lapangan dapat dikarakteristikkan sebagai tampilan kekuatan, daya, dan teknik yang sangat agresif. Kejadian tola peluru di trek dan lapangan menggunakan pola teknis yang berupaya untuk membuat pengumpulan kekuatan dengan menciptakan torsi antar bagian yang berbeda. tubuh melalui stretch reflexes. Untuk alasan ini, sangat penting bagi tubuh untuk menyesuaikan secara optimal untuk melakukan teknik-teknik ini. Mengingat sifat peristiwa pelemparan yang eksplosif dan urutan kontraksi yang tepat yang harus terjadi, rutinitas pelatihan dirancang untuk menekankan kekuatan dan fleksibilitas (Judge, 2008).

Tolak peluru merupakan olahraga yang membutuhkan daya ledak otot dalam melakukan awalan agar mendapatkan tolakan yang optimal semua itu dapat dilihat pada saat kita melakukan tolak peluru dengan gerakan meluncur. Karena itu, latihan yang ditentukan untuk para atlet sangat penting untuk kesuksesan mereka. Daya ledak otot tungkai dan otot lengan sering di sebut power, karena proses kerjanya anaerobik yang memerlukan waktu tercepat dan tenaga yang kuat, kemampuan ini merupakan kombinasi antara kekuatan dan kecepatan. Cole, \& Panariello. (2016:3), kekuatan adalah kemampuan otot untuk menghasilkan kekuatan maksimal, yang dikembangkan dalam latihan dengan intensitas latihan yang lebih tinggi (berat badan menjadi terangkat).

Power adalah kuantitas mekanis yang mengekspresikan tingkat kinerja pekerjaan (Enoka R. 1994), dan sangat tergantung pada kemampuan untuk mengerahkan kekuatan setinggi mungkin (mis. kekuatan maksimum) (Schmidtbleicher, 1992; Stone, 2003ab). Kekuatan otot, didefinisikan sebagai kemampuan otot untuk menghasilkan kekuatan (Robles et al.,2011). keterbatasan fungsional serta tingkat aktivitas fisik yang rendah dikaitkan dengan kekuatan otot yang rendah (Bernabeu-Mora et al.,2017; Rausch Osthoff et al.,2013).

Selain itu kekuatan otot, yang didefinisikan sebagai kemampuan untuk menghasilkan energi (dalam Joule) dalam waktu singkat, dapat dinyatakan oleh produk gaya dan kecepatan (Reidand Fielding,2012). Kekuatan otot telah terbukti sangat terkait dengan kapasitas fungsional dan mobilitas, seperti kecepatan dari kekuatan otot (Accettura, Brenneman, Stratford, dan Maly, 2015).

Berbagai protokol dapat digunakan untuk mengevaluasi seberapa cepat sistem neuromuskuler menghasilkan kekuatan. Tingkat perkembangan torsi dari interaksi isometrik adalah ukuran yang menunjukkan kekuatan eksplosif, yang didefinisikan oleh Maffiuletti dan rekannya sebagai "kemampuan untuk meningkatkan torsi secepat mungkin selama kontraksi sukarela terwujud dari tingkat rendah atau tingkat istirahat". Ukuran yang lebih spesifik dari pengembangan kekuatan cepat termasuk ukuran kekuatan otot, seperti daya rata-rata puncak selama isokinetik dan isotonik (Reid dan Fielding, 2012).

Berdasarkan kemampuan dari kontraksi otot, baik otot tumgkai maupun otot lengan secara isokinetik dan isotonik, maka kami berhipotesis 
164 Kontribusi daya ledak otot tungkai dan daya ledak otot lengan terhadap kemampuan tolak peluru teknik O 'breinAli Mardius, Yuni Astuti, Kibadra

bahwa daya ledak otot tungkai dan daya ledak otot lengan memberikan kontribusi pada cabang olahraga aletik nomor tolak yaitu tolak peluru dengan teknik o'brein.

\section{METODE}

Penilitian ini akan dilaksanakan di kampus II Fakultas Keguruan dan Ilmu Pendidikan Universitas Bung Hatta, Penelitian tergolong pada jenis penelitian kuantitatif dengan menggunakan teknik analisis korelasional yang dilanjutkan dengan menghitung besarnya kontribusi variabel bebas terhadap variabel terikat. Adapun variabel yang dihubungkan dalam penelitian ini adalah daya ledak otot tungkai (XI) dan daya ledak otot lengan (X2), sedangkan variabel terikatnya yaitu kemampuan tolakan dalam nomor tolak peluru (Y). Tes untuk mengambil data daya ledak otot tungkai menggunakan "standing broad jump"(Verducci, 1980:199).

Untuk mengukur seberapa besar daya ledak otot lengan dilakukan tes dengan menggunakan bola one hand medicine ball put (Ismaryati, 2006: 64). Sedangkan untuk mengukur kemampuan Tolak Peluru menggunakan Tes Menurut Persatuan Atletik Seluruh Indonesia (PASI) pada tahun (1993:100).Teknik analisis data yang digunakan adalah teknik analisis, korelasi sederhana dan ganda. Hipotesis 1 dan 2 dianalisis dengan korelasi dan regresi, sederhana sedangkan hipotesis 3 dianalisis dengan korelasi dan regresi ganda. Sebelum melakukan analisis terhadap data diatas dilakukan uji persyaratan:

1) Uji normalitas untuk mengetahui apakah data berasal dari populasi yang berdistribusi normal, dilakukan dengan $U j i$ Lilliefors.

2) Uji Linearitas regresi $X$, atas $Y$ dan $X_{2}$ atas Y menggunakan teknik regresi sederhana.
3) Uji independens variabel bebas, digunakan untuk memeriksa apakah variabel daya ledak otot tungkai dan daya ledak otot lengan benar-benar bebas atau satu sama lainnya tidak berkorelasi secara signifikan, sehingga prediktor benar-benar murni nilai prediksinya.

Analisis korelasi dan regresi ganda, analisis ini digunakan untuk mengetahui kontribusi variabel daya ledak otot tungkai (Xi) dan daya ledak otot lengan (X2) secara bersama-sama terhadap kemampuan tolakan dalam tolak peluru (Y), keberartian korelasi dan persamaan regresinya menggunakan Uji F

\section{HASIL DAN PEMBAHASAN}

Data penelitian ini terdiri dari: kemampuan tolak peluru sebagai variabel terikat $(\mathrm{Y})$, daya ledak otot tungkai $\left(\mathrm{X}_{1}\right)$, daya ledak otot lengan $\left(\mathrm{X}_{2}\right)$, sebagai variabel bebas, pengolahan data disajikan secara berurutan sebagai berikut:

Dari hasil pengukuran sampel dalam penelitian ini yang terdiri dari 30 orang atlet, diperolehjarak terjauh daya ledak otot tungkai menggunakan tes standing broad jump yaitu 2,24 meter danjarak terdekat 1,49 meter. Nilai rata-rata yaitu 1,83, kemudian standar deviasi0,19 dan titik tengah (median) yaitu 1,87. Distribusi frekuensi dapat digambarkan dalam tabel 3.

Tabel 1. Distribusi Frekuensi Daya Ledak Otot Tungkai $\left(\mathrm{X}_{1}\right)$

\begin{tabular}{llll}
\hline \multirow{2}{*}{ No } & \multirow{2}{*}{ Kelas interval } & \multicolumn{2}{l}{ Frekuensi } \\
\cline { 3 - 4 } & & Absolut & Relatif \\
\hline 1 & $2,09-2,24$ & 3 & 10 \\
2 & $1,93-2,08$ & 6 & 20 \\
3 & $1,77-1,92$ & 9 & 30 \\
4 & $1,61-1,76$ & 8 & 26,67 \\
5 & $1,45-1,60$ & 4 & 13,33 \\
\hline \multicolumn{2}{l}{ Jumlah } & 30 & 100 \\
\hline
\end{tabular}


165 Kontribusi daya ledak otot tungkai dan daya ledak otot lengan terhadap kemampuan tolak peluru teknik O 'breinAli Mardius, Yuni Astuti, Kibadra

Tabel 1 menunjukkan bahwa yang berada pada kelas interval $1,45-1,60$ yaitu ada 4 orang $(13,33 \%)$, kelas interval $1,61-1,76$ yakni sebanyak 8 orang $(26,67 \%)$ dan kelas interval 1,77 - 1,92 adalah sebanyak 9 orang (30\%). Selanjutnya untuk kelas interval 1,93 - 2,08 yaitu ada 6 orang (20\%) dan kelas interval 2,09 - 2,24 yaitu 3 orang (10\%). Untuk lebih jelas dapat dilihat grafiknya pada gambar 1 .

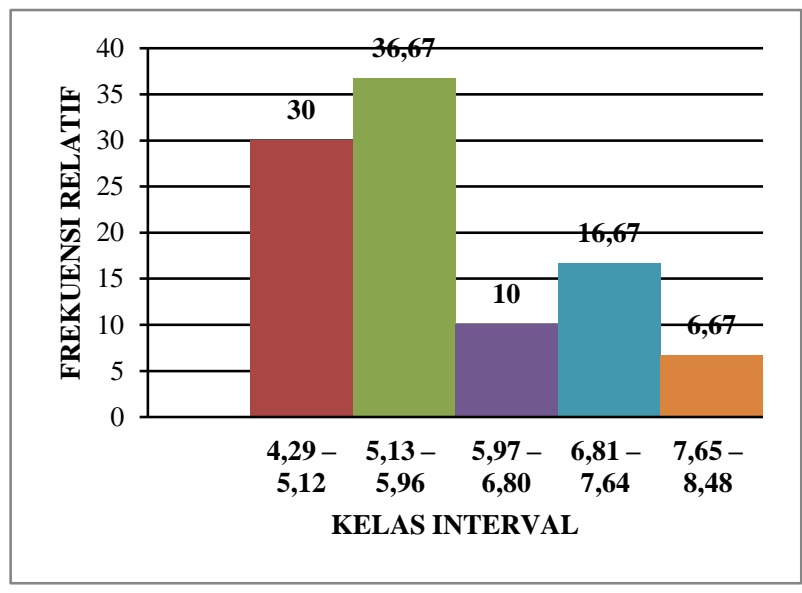

\section{Gambar 1. Histogram Daya Ledak Otot Tungkai $\left(\mathrm{X}_{1}\right)$}

Pengukuran dan analisis variabel daya ledak otot lengan diperoleh data tertinggi 10 meter dan data terendah yaitu 5,39. Untuk nilai rata-rata hitung diperoleh 7,40, standar deviasi diperoleh 1,23 dan nilai tengah yaitu 7,7. Untuk lebih jelasnya dapat dilihat pada tabel 2.

Tabel 2. Distribusi Frekuensi Daya Ledak Otot Lengan $\left(\mathrm{X}_{2}\right)$

\begin{tabular}{cccc}
\hline \multirow{2}{*}{ No } & \multirow{2}{*}{ Kelas interval } & \multicolumn{2}{c}{ Frekuensi } \\
\cline { 3 - 4 } & & Absolut & Relatif \\
\hline 1 & $9,08-10,00$ & 3 & 10 \\
2 & $8,15-9,07$ & 5 & 16,67 \\
3 & $7,22-8,14$ & 11 & 36,67 \\
4 & $6,29-7,21$ & 5 & 16,67 \\
5 & $5,36-6,28$ & 6 & 20 \\
\hline & Jumlah & $\mathbf{3 0}$ & $\mathbf{1 0 0}$ \\
\hline
\end{tabular}

\section{Berdasarkan data pada Tabel 4 di halaman} sebelumnya maka jelaslah bahwa atlet yang berada pada kelas interval $5,36-6,28$ adalah 6 orang (20\%), kelas interval 6,29 - 7,21 yaitu 5 orang $(16,67 \%)$ dan kelas interval 7,22 - 8,14 yaitu sebanyak 11 orang $(36,67)$. Selanjutnya untuk kelas interval $8,15-9,07$ ada 5 orang $(16,67 \%)$ dan kelas interval 9,08 - 10,00 adalah 3 orang (10\%). Untuk lebih jelas lihat grafik pada gambar 2

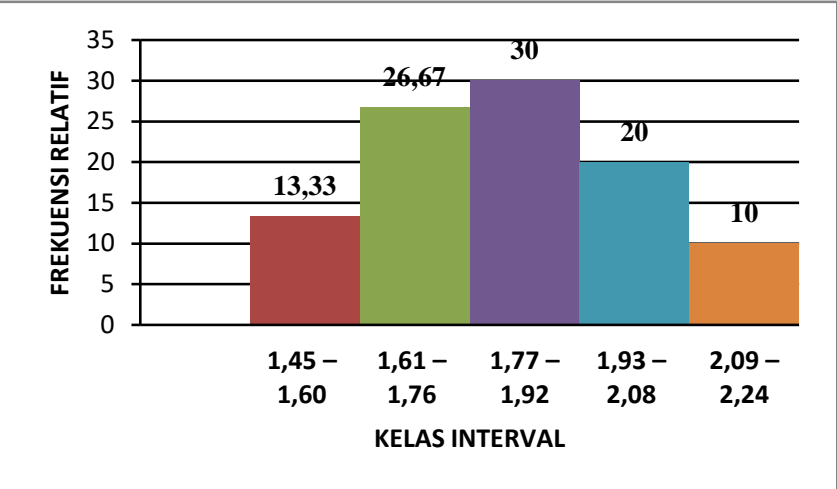

Gambar 2. Histogram Daya Ledak Otot Lengan $\left(\mathbf{X}_{2}\right)$

Dari hasil pengukuran data variabel kemampuan tolak peluru atlet atletik UKO Fakultas Ilmu Keolahragaan Universitas Negeri Padang diperoleh skor jarak terjauh yaitu 8,48 danjarak terdekat 4,32. Sedangkan nilai rata-rata hitung diperoleh 5,7, standar deviasi yakni 1,11 dan nilai tengah (median) yaitu 6,40.Distribusi frekuensi hasil kemampuan tolak peluru dapat digambarkan dalam tabel 3.

Tabel 3. Distribusi Frekuensi Data Kemampuan Tolak Peluru (Y)

\begin{tabular}{cccc}
\hline \multirow{2}{*}{ No } & Kelas & \multicolumn{2}{c}{ Frekuensi } \\
\cline { 3 - 4 } & interval & Absolut & Relatif \\
\hline 1 & $7,65-8,48$ & 2 & 6,67 \\
2 & $6,81-7,64$ & 5 & 16,67 \\
3 & $5,97-6,80$ & 3 & 10 \\
4 & $5,13-5,96$ & 11 & 36,67 \\
5 & $4,29-5,12$ & 9 & 30 \\
\hline & Jumlah & $\mathbf{3 0}$ & $\mathbf{1 0 0}$ \\
\hline
\end{tabular}

Dari tabel 3 di atas data kemampuan tolak peluru atlet atletik UKO FIK UNP yang berada pada kelas interval 4,29 - 5,12 adalah 9 orang $(30 \%)$, kelas interval 5,13 - 5,96 yaitu sebanyak 11 orang $(36,67 \%)$ dan kelas interval 5,97 - 6,80 yaitu 3 orang (10\%). Sedangkan kelas interval 6,81 
166 Kontribusi daya ledak otot tungkai dan daya ledak otot lengan terhadap kemampuan tolak peluru teknik O 'breinAli Mardius, Yuni Astuti, Kibadra

- 7,64 adalah 5 orang $(16,67 \%)$ dan kelas interval

$7,65-8,48$ ada 2 orang $(6,67 \%)$.

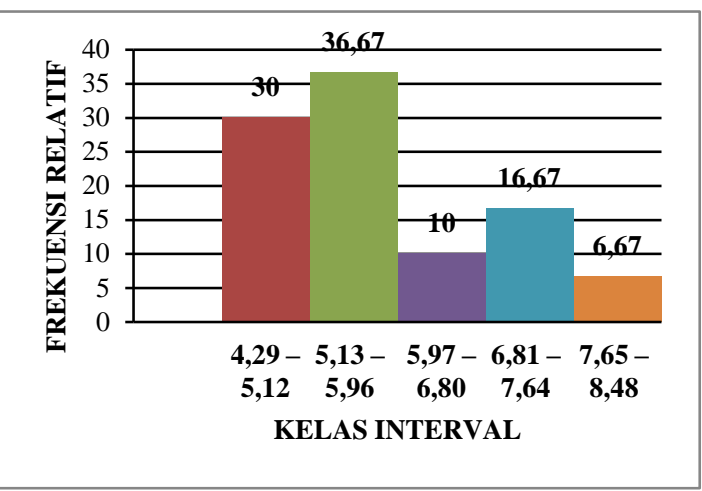

Gambar 3. Histogram Data Hasil Tes Kemampuan Tolak Peluru(Y)

Uji normalitas dilakukan dengan menggunakan uji Lilliefors dengan taraf nyata $(\alpha)$ $=0.05$, kriteria pengujian adalah bahwa $\mathrm{H}_{\mathrm{o}}$ ditolak apabila $\mathrm{L}_{\mathrm{o}}$ yang diperoleh dari data pengamatan melebihi $L_{t}$ dan sebaliknya $H_{o}$ diterima apabila $L_{t}$ lebih besar dari $L_{o}$ secara sederhana dapat digunakan rumus sebagai berikut:

$\mathrm{H}_{\mathrm{o}}=$ ditolak apabila $\mathrm{L}_{\mathrm{o}}>\mathrm{L}_{\mathrm{t}}\left(\mathrm{L}_{\text {tabel }}\right)$

$\mathrm{H}_{\mathrm{a}}=$ diterima apabila $\mathrm{L}_{\mathrm{o}}<\mathrm{L}_{\mathrm{t}}\left(\mathrm{L}_{\text {tabel }}\right)$

Hasil perhitungan lengkap uji normalitas dapat dilihat pada lampiran dansebagai rangkumannya terlihat pada tabel 4 .

Tabel 4. Rangkuman Hasil Uji Normalitas Data Penelitian

\begin{tabular}{lccc}
\hline \multicolumn{1}{c}{ Variabel } & $\mathbf{L}_{\text {obsevasi }}$ & $\mathbf{L}_{\text {tabel }}$ & $\begin{array}{c}\text { Kesim } \\
\text { pulan }\end{array}$ \\
\hline $\begin{array}{l}\text { Daya ledak otot tungkai } \\
\left(\mathrm{X}_{1}\right)\end{array}$ & 0,074 & 0,161 & Normal \\
$\begin{array}{l}\text { Daya ledak otot lengan } \\
\left(\mathrm{X}_{2}\right)\end{array}$ & 0.110 & 0,161 & Normal \\
$\begin{array}{l}\text { Kemampuan tolak peluru } \\
(\mathrm{Y})\end{array}$ & 0,157 & 0,161 & Normal \\
\hline
\end{tabular}

Berdasarkan hasil perhitungan uji normalitas variabel penelitian di atas ditemukan bahwa harga $\mathrm{L}_{\text {observasi }}\left(\mathrm{L}_{\mathrm{o}}\right)$ yang diperoleh lebih kecil dari harga $\mathrm{L}_{\text {tabel }}\left(\mathrm{L}_{\mathrm{t}}\right)$ pada taraf nyata 0.05 . Dengan demikian dapat disimpulkan bahwa semua kelompok data pada penelitian ini diambil dari populasi yang berdistribusi normal sehingga dapat digunakan untuk pengujian hipotesis penelitian.

Sebelum sampai pengujian hipotesis terlebih dahulu dilakukan perhitungan koefisien korelasi antara variabel bebas yaitu: dalam rangka uji independensi. Hasil analisis korelasi antara daya ledak otot tungkai dan otot lengan atau interkorelasi antara variabel bebas dapat dilihat pada Tabel 5.

Tabel 5. Rangkuman Hasil Uji Indenpendensi Antara Variabel Bebas Daya Ledak Otot Tungkai dan Otot Lengan

\begin{tabular}{ccccc}
\hline $\begin{array}{c}\text { Korelasi } \\
\text { Antara }\end{array}$ & $\begin{array}{c}\text { Koefisi } \\
\text { en } \\
\text { Korelas } \\
\mathbf{i}\end{array}$ & $\begin{array}{c}\text { Koefisien } \\
\text { Determi } \\
\text { nasi }\end{array}$ & $\begin{array}{c}\mathbf{r}_{\text {tabe }} \\
\mathbf{1}=\mathbf{0 , 0}\end{array}$ & $\begin{array}{c}\text { Kesim } \\
\text { pulan }\end{array}$ \\
\hline $\mathrm{X}_{1}$ dan & 0,310 & 0,0961 & 0,36 & Tidak \\
$\mathrm{X}_{2}$ & & & 1 & $\begin{array}{c}\text { Terda } \\
\text { pat } \\
\end{array}$ \\
& & & & korel \\
& & & & asi \\
\hline
\end{tabular}

Berdasarkan uji keberartian korelasi antara pasangan skor daya ledak otot tungkai $\left(\mathrm{X}_{1}\right)$ dengan daya ledak otot lengan $\left(\mathrm{X}_{2}\right)$, sebagaimana pada tabel 6 diperoleh $r_{\text {hitung }}<r_{\text {tabelpada taraf signifikansi }}$ $\alpha=0,05$. Dengan demikian dapat disimpulkan bahwa tidak terdapat hubungan yang signifikan antara variabel bebas yaitu daya ledak otot tungkai $\left(\mathrm{X}_{1}\right)$ dengan daya ledak otot lengan $\left(\mathrm{X}_{2}\right)$, sengan kata lain dapat diartikan bahwa tidak terdapat kontaminasi hubungan antara variabel bebas dalam kaitannya dengan variabel terikat.

Hal ini dapat diartikan bahwa daya ledak otot tungkai daya ledak otot lengan, baik secara sendiri-sendiri ataupun secara bersama memberikan kontribusi secara signifikan terhadap kemampuan tolak peluru yang didukung oleh data penelitian, selanjutnya dilakukan pembahasan terhadap hasil pengujian hipotesis.

Pada uji hipotesispertama yaitu daya ledak otot tungkai berkorelasi dengan kemampuan tolak 
167 Kontribusi daya ledak otot tungkai dan daya ledak otot lengan terhadap kemampuan tolak peluru teknik O 'breinAli Mardius, Yuni Astuti, Kibadra

peluru secera signifikan. Hal ini dibuktikan oleh koefisien korelasi yang ditemukan sebesar 0,379 dan atas dasar hasil koefisien ini, ditemukan kontribusi daya ledak otot tungkai terhadap kemampuan tolak peluru sangat signifikan dengan koefisien determinasi sebesar $14,36 \%$, selebihnya dipengaruhi oleh variabel yang lain seperti : kelentukan, koordinasi dan keseimbangan. Dapat diartikan semakin baik daya ledak otot tungkai seseorang maka semakin baik pula kemampuan tolak peluru.

Daya ledak adalah kombinasi atau perpaduan dua unsur kondisi fisik yaitu kekuatan dan kecepatan yang terealisasi dalam bentuk kemampuan otot mengatasi beban dengan kecepatan kontraksi yang tinggi . Kekuatan yang dimaksudkan disini diartikan sebagai kemampuan otot atau sekelompok otot yaitu otot tungkai mengatasi beban, sedangkan kecepatan merupakan menunjukkan cepat atau lambatnya otot berkontraksi mengatasi beban tersebut.

Bila dilihat besar kontribusi daya ledak otot tungkai terhadap kemampuan atlet UKO Fakulatas Ilmu Keguruan dan Ilmu Pendidikan Universitas Bung Hatta Padang cukup besar. Kontribusi atau sumbangan kemampuan otot atau sekelompok tungkai atlet dalam mengatasi beban, baik beban tubuh sendiri maupun beban peluru yang digerakan oleh tubuh dengan kontraksi otot yang sangat cepat. Sehingga menghasilkan lemparan peluru jauh dari tubuhnya dalam waktu yan sangat cepat/singkat.

Selanjutnya untuk mengetahui hubungan antar variabel yang mana skor pada suatu variabel dapat digunakan untuk memprediksi skor pada variabel lainnya dilakukan analisis regresi linier sederhana. Dari hasil analisis diperoleh persamaan regresi $\hat{\mathrm{Y}}=1,77+2,20 \mathrm{X}_{1}$. Artinya atlet yang memiliki kemampuan daya ledak otot tungkai dengan baik, maka akan menghasilkan power pada saat melakukan tolakkan gerakan berputar pada kaki kanan ke arah sector lemparan dan sisi kanan tubuh berputar kedepan mengelilingi kaki kiri yang diluruskan, sehingga menghasilkan tolakkan peluru semakin jauh . sebaliknya apabila atlet memiliki kemampuan daya ledak otot tungkai rendah akan menghasilkan tolakkan peluru menjadi lemah dan dekat.

Berpedoman pada hasil temuan dan uraian di atas, jelaslah bawa kemampuan daya ledak otot tungkai atlet atletik UKO FKIP Bung Hatta penting artinya untuk meningkatkan kemampuan tolak peluru. Terutama daya ledak asiklik, seperti yang dikemukakan oleh Syafruddin (2011:108) bahwa "daya ledak asikklik sangat cocok untuk olahraga tolak peluru yang struktur gerakannya terdiri dari tiga fase (fase persiapan, fase pelaksanaan dan fase akhir) secaa utuh seperti gerakan tolak peluru".

Pada uji hipotesis kedua yaitu daya ledak otot lengan berkorelasi dengan kemampuan kemampuan kemampuan tolak peluru secara signifikan. Hal ini dibuktikan oleh koefisien korelasi yang ditemukan sebesar 0,438. Atas dasar hasil koefisien korelasi ini, ditentukan kontribusi daya ledak otot lengan terhadap kemampuan tolak peluru sangat signifikan dengan koefisien determinasi sebesar 19,18\%.

Selanjutnya untuk mengetahui hubungan antar variabel yang mana skor pada suatu variabel lainnya dapat digunakan untuk memprediksi skor pada variabel lainnya dilakukan analisis regresi linier sederhana. Dari hasil analisis diperoleh persamaan regresi $\hat{Y}=2,86+9,55 \mathrm{X}_{2}$. Temuan ini dapat diartikan daya ledak otot lengan mempunyai hubungan secara signifikan dan diterima kebenarannya secara empiris. Dengan demikian jelaslah bahwa semakin baik kemampuan daya ledak otot lengan atlet atletik UKO FKIP Bung Hatta, maka semakin baik kemampuan tolak pelurunya. 
168 Kontribusi daya ledak otot tungkai dan daya ledak otot lengan terhadap kemampuan tolak peluru teknik O 'breinAli Mardius, Yuni Astuti, Kibadra

Hubungan antara daya ledak otot lengan dengan kemampuan tolak peluru, dapat dilihat pada saat atlet melakukan gerakan mendorong lengan sekuat-kuatnya dari belakang dengan berputar mengikuti puturan tubuh, dan tangan yang memegang peluru yang disandarkan pada leher samping, dan tangan kiri diangkat untuk menyeimbangkan tubuh. Gerakan ini terjadi sangat erat hubungan dengan explosive power lengan yang dimiliki atlet, sehingga kemampuan tolak peluru semakin baik.

Dengan demikian dapat dikatakan bahwa kemampuan daya ledak otot lengan berada antara kekuatan maksimal dan kecepatan gerakan, yang cendrung bergerak lebih kearah kecepatan gerakan atau kekuatan maksimal menurut besarnya beban/hambatan. Dalam olahrag tolak peluru seorang atlet dituntut tidak hanya memiliki kekuatan otot maksimal, akan tetapi juga harus memiliki kecepatan yang tinggi, karena dia harus mampu menolak atau melempar peluru sejauh mungkin dari tubuhnya dengan waktu yang sangkat singkat.

Pada uji hipotesis keempat yaitu daya ledak otot tungkai dan daya ledak otot lengan secara bersama berkorelasi dengan kemampuan kemampuan tolak peluru secara signifikan. Hal ini dibuktikan oleh koefisien korelasi ganda yang ditemukan sebesar 0,507. Atas dasar hasil koefisien korelasi ganda ini, ditemukan kontribusi secara bersama daya ledak otot tungkai dandaya ledak otot lenganterhadap kemampuan kemampuan tolak peluru sangat signifikan dengan koefisien determinasi sebesar 25,70\%.

Selanjutnya untuk mengetahui hubungan antar variabel yang mana skor pada suatu variabel dapat digunakan untuk memprediksi skor pada variabel lainnya dilakukan analisis linier sederhana. Dari hasil analisis diperoleh persamaan regresi $\hat{Y}=-0,56+1,57 X_{1}+0,32 X_{2} . \quad$ Artinya secara bersama-sama daya ledak otot tungkai dan daya ledak otot lengan mempunyai hubungan secara signifikan dengan kemampuan tolak peluru atlet atletik UKO FKIP Bung Hatta, dan diterima kebenarannya secara empiris.

Sudah dijelaskan pada bagian terdahulu bahwa daya ledak sebagai produk dari dua kemampuan yaitu kekuatan dan kecepatan untuk melakukan force maksimum dalam waktu yang sangat cepat. Hal ini tentunya berkaitan dengan dengan kualitas otot yang dimiliki seseorang dan tidak dapat dipisahkan dengan fungsi utama dari jaringan otot. Fungsi utama dari jaringan otot yaitu: untuk menghasilkan gerakan lewat kemampuannya berkontraksi dan membangun ketegangan. Kualitas otot ini didapatkan dari atihan, oleh sebab itu untuk meningkatkan kemampuan tolak peluru, terlebih dahulu ditingkatkan kualitas ototnya, terutama otot yang dominan dibutuhkan seperti otot tungkai dan otot lengan.

Di samping itu sudah diketahui bahwa kontribusi atau sumbangan daya ledak otot tungkai dan daya ledak otot lengan secara bersama sama adalah 25,70\%, dan Sisanya sebesar 74,30\% ditentukan oleh variabel lain yang tidak diperhitungkan dalam penelitian ini. Oleh sebab itu perlu atlet ketahui dan pahami bahwa ada faktorfaktor lain yang dapat mempengaruhi kemampuan tolak peluru. Diantaranya adalah kelentukan tubuh, koordinasi gerakan, dan penguasaan teknik seperti sikap kaki, sikap lengan, sikap badan dan teknik atau cara pegangan peluru pada tangan.

\section{SIMPULAN}

Berdasarkan analisis dan pembahasannyang telah dijelaskan diatas maka dapat uraikan beberapa kesimpulan:

1. Daya ledak otot tungkai memberikan kontribusi terhadap kemampuan tolak peluru 
169 Kontribusi daya ledak otot tungkai dan daya ledak otot lengan terhadap kemampuan tolak peluru teknik O 'breinAli Mardius, Yuni Astuti, Kibadra

atlet atletik UKO FKIP Bung Hatta adalah sebesar $14,36 \%$,

2. Daya ledak otot lengan memberikan kontribusi terhadap kemampuan tolak peluru atlet UKO FKIP Bung Hatta yaitu sebesar $19,18 \%$,

3. Daya ledak otot tungkai dan daya ledak otot lengan memberikan kontribusi terhadap kemampuan tolak peluru atlet UKO FKIP Bung Hatta yakni sebesar 25,70\%.

Ukuran daya dinamis, dinilai dengan standar isotonik pada dynamometer yang terkomputerisasi, dapat diandalkan dan secara signifikan berkorelasi dengan fungsi fisik. Di antara ukuran yang berbeda, daya rata-rata adalah ukuran daya yang menunjukkan keandalan terbaik dan hubungan yang lebih kuat dengan mobilitas dan fungsi dari otot (Bui et al, 2019). Jadi daya ledak otot tungkai dan daya ledak otot lengan yang baik dapat memberikan kontribusi kepada kemampuan tolak peluru atlet atletik yang mengunakan teknik o'brein.

\section{DAFTAR PUSTAKA}

Accettura A, Brenneman E, Stratford P, Maly M2015Kneeextensor power relates to mobility performance in peoplewith knee osteoarthritis: Cross-sectional analysis. PhysicalTherapy 95: 989-995.

Bernabeu-Mora R, Gimenez-Gimenez LM, Montilla-Herrador J, Garcia-Guillamon G, Garcia-Vidal JA,Medina-Mirapeix F. (2017). Determinants of each domainof the short physical performance battery in COPD.Internatioal Journal of Chronic Obstructive PulmonaryDisease 12: 2539-2544.

Bui, K.-L., Maia, N., Saey, D., Dechman, G., Maltais, F., Camp, P. G., \& Mathur, S. (2019). Reliability of quadriceps muscle power and explosive force, and relationship to physical function in people with chronic obstructive pulmonary disease: an observational prospective multicenter study. Physiotherapy Theory and Practice, 1-9. doi:10.1080/09593985.2019.1669233.
Cole, Brian \& Panariello, Rob. (2016). Basketball Anatomy. Canada: Human Kinetics.

Enoka R. (1994). Neuromechanical Basis of Kinesiology, (2nd Ed.). Champaign, IL: Human Kinetics.

Judge LW, Young M. (2011). The Shot Put Handbook. Monterey, CA:Coaches ChoicePublishing.

Judge LW. (2008). The Complete Track and Field Coaches' Guide to Conditioning for theThrowing Events. Monterey, CA: Coaches Choice Publishing.

Rausch Osthoff AK, Taeymans J, Kool J, Marcar V, VanGestel AJ. (2013). Association between peripheral musclestrength and daily physical activity in patients withCOPD: A systematic literature review and meta-analysis.Journal of Cardiopulmonary Rehabilitation and Prevention33: 351-359.

Reid KF, Fielding RA. (2012). Skeletal muscle power: A criticaldeterminant of physical functioning in older adults. Exercise and Sport Sciences Reviews 40: 4-12.

Robles PG, Mathur S, Janaudis-Fereira T, Dolmage TE,Goldstein RS, Brooks D. (2011). Measurement of peripheralmuscle strength in individuals with chronic obstructivepulmonary disease: A systematic review. Journal ofCardiopulmonary Rehabilitation and Prevention 31:11-24.

Schmidtbleicher D. (1992). Training for power events. In P.V. Komi (Ed.), Strength and Power in Sports (pp. 381-395). London: Blackwell Scientific Publications.

Stone MH, O’Bryant H, McCoy L, Coglianese R, Lehmkuhl M, Schilling B. (2003a). Power and maximum strength relationships during performance of dynamic and static weighted jumps. $J$ Strength Cond Res 17: 140-147.

Stone MH, Sanborn K, O’Bryant HS, Hartman M, Stone ME, Proulx C, Hruby J. (2003b.). Maximum strength-power performance relationships in collegiate throwers. $J$ Strength Cond Res 17: 739-745. 